\title{
MANAGING INTERNATIONAL BRANCH CAMPUSES: WHAT DO WE KNOW?
}

\section{Introduction}

Over the last decade, the growth of the international branch campus (IBC) has been one of the most striking developments in the internationalisation of higher education. In their most recent survey for the Observatory on Borderless Higher Education (OBHE), Lawton and Katsomitros (2012) estimated that there were around 200 IBCs in existence across the world, with another 37 in development (see also British Council 2013, C-BERT n.d.). The Middle East emerged in the mid-2000s as a host region (Donn and Al Manthri 2010, Wilkins 2010, Miller-Idriss and Hanauer 2011). Education City in Qatar, for example, houses the satellite campuses of Cornell, Texas A\&M, Carnegie Mellon and UCL. Dubai International Academic City is home to Heriot-Watt, BITS Pilani and Amity University.

The other major host region is east and south-east Asia (Banks and McBurnie 1999, Garrett and Verbik 2003, Huang 2003, 2007, Helms 2008, Gu 2009, Ilieva 2011, Welch 2011, Ziguras and McBurnie 2011). The University of Nottingham has campuses in Malaysia and China (Ennew and Yang 2009); the University of Liverpool has a branch campus in China in partnership with Xi'an Jiaotong University (Feng 2013). China now has several Sino-foreign universities. The Universities of Newcastle, Southampton and Reading have all recently opened campuses in Iskander, Malaysia.

The growth of IBCs is at the leading edge of what has become known as 'transnational education'; that is, universities providing education to foreign students who remain in their own countries. The phenomenon of transnational education is generally seen as the most advanced stage in the internationalisation of higher education (Mazzarol et al 2003, Hatakenaka 2004, Marginson and Van der Wende 2007, Doorbar and Bateman 2008, Healey 2008). Universities start to internationalise their teaching activities by recruiting foreign students to their home campuses (De Wit 2002, Mazzarol and Soutar 2002, Bennell and Pearce 2003, Altbach 2004). This is sometimes termed 'export education', as it is the educational equivalent of exporting services like tourism (where the foreign tourist has to visit the exporting country to consume the service). For universities in the most advanced export education countries like the UK and Australia, approximately one in five university students are foreign (OECD 2013).

There are, however, limits to the growth of traditional export education. Universities face capacity constraints. International students tend to be concentrated in subjects like business and engineering, which offer graduates the highest rate of return (in terms of higher lifetime earnings) on the costs of tuition and living while studying. International student numbers cannot, therefore, be expanded beyond a certain point without distorting the shape and academic character of a university.

Perhaps more fundamentally, there is a limit to the number of students who are willing and able (financially and culturally) to study in a foreign country (British Council 2012, 2013, Healey 2013). While the total number of students in tertiary education has grown rapidly over the last 30 years, the percentage that study outside their own country (ie, who are 'internationally-mobile') has remained fairly constant at around 2\% (see Table 1). 
Table 1: Global and internationally-mobile tertiary enrolments

\begin{tabular}{|l|c|c|c|c|c|c|c|}
\hline & $\mathbf{1 9 8 0}$ & $\mathbf{1 9 8 5}$ & $\mathbf{1 9 9 0}$ & $\mathbf{1 9 9 5}$ & $\mathbf{2 0 0 0}$ & $\mathbf{2 0 0 5}$ & $\mathbf{2 0 1 0}$ \\
\hline Global tertiary enrolments (m) & 51.2 & 60.3 & 68.7 & 81.7 & 99.9 & 139.0 & 178.0 \\
\hline Internationally-mobile (m) & 1.1 & 1.1 & 1.3 & 1.7 & 2.1 & 3.0 & 4.1 \\
\hline Internationally mobile as \% total & $2.1 \%$ & $1.8 \%$ & $1.9 \%$ & $2.1 \%$ & $2.1 \%$ & $2.2 \%$ & $2.3 \%$ \\
\hline
\end{tabular}

Source: UNESCO 1998, n.d., OECD 2013

Transnational education allows universities to increase their international enrolments by offering their qualifications in third countries, competing for the $98 \%$ of the market for higher education that is not internationally mobile. Moreover, by establishing themselves in markets where the local higher education sector is too underdeveloped to satisfy demand, universities may actually increase global participation in higher education (Sidhu 2007, Vincent-Lancrin 2007, Lien 2008, Lien and Wang 2012, Tsiligiris 2013, McNamara and Knight 2014).

Transnational education takes various forms (Knight 2005, 2006, 2007, McBurnie and Ziguras 2007, 2009, Burgess and Berquist 2012). Universities can offer degrees by distancelearning or sub-contract local delivery partners to market, teach and assess their degrees. The IBCs of some of the UK's leading universities are, however, the most tangible and highprofile form of transnational education. In the case of the Universities of Nottingham and Newcastle, their campuses in Asia are architecturally designed to mimic the most iconic buildings on the home campus. These IBCs are an extraordinary projection of 'soft power' and widely viewed as the 'third wave' in the internationalisation of higher education (Mazzarol et al 2003, Altbach and Knight 2007, Altbach et al 2009).

In terms of the way they operate, relatively little is known about these IBCs (Girdzijauskaite and Radzeviciene 2014). They are generally presumed to be foreign outposts of the home university, operating as remote satellite campuses, but adhering to standard procedures and academic processes. Often, they are likened to foreign subsidiaries of multinational corporations (Bhanji 2008, Gore 2012, Salt and Wood 2014) and accused by their critics of amounting to 'academic colonialism' (eg, Nguyen et al 2009). In practice, however, the IBCs vary considerably in terms of their ownership and governance structures, their financial base and the regulatory environment in which they operate (Rumbley and Altbach 2007, Healey and Bordogna 2014). Much of the detail is shrouded in commercial secrecy.

Moreover, of the authoritative studies of IBCs that have been undertaken, most are classified as 'grey literature', representing work by organisations by the Quality Assurance Agency (2009, 2010, 2011, 2012, 2014), the British Council (Drew et al 2006, British Council 2013), the Observatory for Borderless Higher Education (Garrett 2002, Garrett and Verbik 2003, 2004, Garrett 2004, Verbik and Merkley 2006, Becker 2009, Lawton and Katsomitros 2012), The UK Higher Education Unit (Fielden 2008) and the Leadership Foundation for Higher Education (eg, Fielden 2011, Emery and Worton 2014). The special feature of this work is that it is aimed at a practitioner audience and often only available to subscribing members.

From the perspective of the higher education sector, the challenge of managing an IBC is an area of great interest. Setting up and running an IBC exposes the home university to very considerable financial and reputational risk. There are a number of high-profile examples of IBCs which have failed and caused serious damage not just to the universities concerned, but the countries form which they originate. The University of New South Wales, for example, withdrew from its UNSW Asia IBC after only one semester in 2007 and a report from the 
state's auditor-generally revealed that the venture has lost just under $\mathrm{A} \$ 50 \mathrm{~m}$, as well as tarnishing the Australian higher education brand in Singapore (Observatory on Borderless Higher Education 2007).

As Girdzijauskaite and Radzeviciene (2014) note, 'an international branch campus is one of the most risky and unexplored entry modes to international markets in higher education and the topic of interest around the globe, however little knowledge has been gathered about this internationalisation mode' (p.301). The purpose of this paper is to review what is presently known about the challenges of managing the IBCs of UK universities. The structure is as follows. First, the definition of an IBC is considered and then the scale and extent of IBCs is briefly outlined. The main part of the paper reviews the literature on the management of IBCs, which is presently in its infancy. To supplement this limited literature, it also draws on cognate areas, to better understand what international business theory suggests might be the challenges of using an IBC as a mode of market entry and, in many cases, the difficulties of managing an IBC which is set up as a foreign joint venture.

\section{What is an international branch campus?}

In an influential report for the Observatory for Borderless Higher Education (OBHE), Becker (2009) defined an international branch campus as 'an offshore operation of a higher education institution which meets the following criteria:

- The unit should be operated by the institution or through a joint venture in which the institution is a partner...in the name of the foreign institution and

- Upon successful completion of the course programme, which is fully taken at the unit abroad, students are awarded a degree from the foreign institution' (p.2).

The OBHE's American counterpart, the Cross-Border Education Research Team (C-BERT) at the State University of New York at Albany, similarly defines an international branch campus as 'an entity that is owned, at least in part, by a foreign education provider; operated in the name of the foreign education provider; engages in at least some face-to-face teaching; and provides access to an entire academic program that leads to a credential awarded by the foreign education provider' (C-BERT n.d.).

A closer look at the 200 or so international branch campuses being monitored by the OBHE and C-BERT reveals that, as Lane and Kinser (2012) observed, getting a clear definition 'is a fairly slippery subject'. In their 2012 report for the OBHE on international branch campuses, Lawton and Katsomitros (2012) acknowledged the impracticality of having a 'permanent definition' (p.7), because universities are constantly repositioning their offshore activities in the light of changing regulatory and competitive environments (see also Healey 2014b).

This is because ownership, academic governance, financial and legal structure varies between IBCs (Lane and Kinser 2013), so that any definition arbitrarily includes some apparent IBCs and excludes others. For example, the OBHE's 2009 definition excludes 'establishments where the programmes offered lead only to double or joint degrees ((eg, Xi'an JiaotongLiverpool University in China)' (Becker 2009, p.3). In the 2012 report, the OBHE modified the definition of an IBC to:

- 'a higher education institution that is located in another country from the institution which either originated it or operates it, with some physical presence in the host country; 
- and which awards at least one degree in the host country that is accredited in the country of the originating institution' (Lawton and Katsomitros 2012, p.7).

The authors noted that the 'broadening of the previous definition is two-fold:

- it includes institutions which also award degrees accredited in the host country, as long as accreditation also exists in the home country. These are usually dual-degree arrangements.

- it includes institutions that offer only part of degree programmes at branch operations' (Lawton and Katsomitros 2012, p.7).

This slightly broadened definition reinstated, for example, Xi'an Jiaotong-Liverpool University as an IBC of the University of Liverpool, as it awards graduates both a Chinese university degree and a Liverpool degree (dual award). Healey and Bordogna (2014) have argued, however, that whether the degree is awarded by the home university, or accredited in the home university's country, is relatively unimportant. Many IBCs have a choice of whether to offer locally-accredited degrees or the home university's (or both) and, in most cases, it is simply a matter of which choice gives the IBC the greater competitive advantage and which is acceptable to the local host government. For example, in some jurisdictions, unless IBCs issue locally-accredited degrees, their graduates cannot be employed in in the country's public sector. Some host governments do not permit IBCs to issue dual degrees (home university and locally accredited). The IBC remains, regardless of the accreditation of the degree, fundamentally an outpost of the home university.

Table 2 shows the sensitivity of the classification system used by difference organisations. A total of 30 UK universities are judged to have one or more IBCs based on their HESA return for 2012/13, their classification by the OBHE in its 2012 report (Lawton and Katsomitros 2012) or C-BERT (March 2014 list). Of these, slightly over half (16 universities) were only deemed to have an IBC by one of the three approaches, eight by two approaches and only six by all three. The total number of UK universities judged to have one or more IBCs varied from 13 (HESA) to 20 (C-BERT). 
Table 2: Number of UK universities with international branch campuses

\begin{tabular}{|c|c|c|c|}
\hline & HESA & C-BERT & OBHE \\
\hline Aberystwyth University & & $\sqrt{ }$ & \\
\hline City University & & $\sqrt{ }$ & $\sqrt{ }$ \\
\hline De Montfort University & & $\sqrt{ }$ & \\
\hline Glasgow Caledonian University & & $\sqrt{ }$ & $\sqrt{ }$ \\
\hline Heriot-Watt University & $\sqrt{ }$ & $\sqrt{ }$ & $\sqrt{ }$ \\
\hline Leeds Metropolitan University & & & $\sqrt{ }$ \\
\hline London Business School & $\sqrt{ }$ & $\sqrt{ }$ & $\sqrt{ }$ \\
\hline Middlesex University & $\sqrt{ }$ & $\sqrt{ }$ & $\sqrt{ }$ \\
\hline Queen Margaret University & & $\sqrt{ }$ & \\
\hline University London College & & $\sqrt{ }$ & $\sqrt{ }$ \\
\hline University of Bolton & & $\sqrt{ }$ & $\sqrt{ }$ \\
\hline University of Bradford & & $\sqrt{1}$ & \\
\hline University of Central Lancashire & & $\sqrt{ }$ & \\
\hline University of Chichester & $\sqrt{ }$ & & \\
\hline University College Birmingham & $\sqrt{ }$ & & \\
\hline University College London & $\sqrt{ }$ & $\sqrt{ }$ & $\sqrt{ }$ \\
\hline University of Exeter & $\sqrt{ }$ & $\sqrt{ }$ & \\
\hline University of Kent & $\sqrt{ }$ & & \\
\hline University of Lancaster & & & $\sqrt{ }$ \\
\hline University of Liverpool & & & $\sqrt{ }$ \\
\hline University of London & & $\sqrt{ }$ & \\
\hline University of Manchester & & $\sqrt{ }$ & $\sqrt{ }$ \\
\hline University of Newcastle-upon-Tyne & $\sqrt{ }$ & $\sqrt{ }$ & $\sqrt{ }$ \\
\hline University of Nottingham & $\sqrt{ }$ & $\sqrt{ }$ & $\sqrt{ }$ \\
\hline University of Southampton & $\sqrt{ }$ & & \\
\hline University of Strathclyde & & & $\sqrt{ }$ \\
\hline University of Surrey & & $\sqrt{ }$ & $\sqrt{ }$ \\
\hline University of Wales Trinity Saint David & $\sqrt{ }$ & & \\
\hline University of Westminster & & & $\sqrt{ }$ \\
\hline University of Wolverhampton & $\sqrt{ }$ & $\sqrt{ }$ & \\
\hline Total No. of UK universities with IBCs & 13 & 20 & 17 \\
\hline
\end{tabular}

Source: HESA, C-BERT, Lawton and Katsomitros (2012)

Reviewing the OBHE's change of definition, Lane and Kinser (2012) argue that it is 'not clear that a single definition can ever fully address all of the parameters of IBC activity without more or less questionable use of judgment calls', but concede that working definitions are needed to operationalize research questions and consider policy implications. For the purposes of this review, an IBC is defined according the current 'working definition' of the OBHE, so that it includes campuses operating under their own brand names.

\section{International branch campuses: the current landscape}

The two main organisations which monitor the growth of IBCs globally are the OBHE and CBERT. The OBHE undertakes regular surveys and has published very detailed reports very few years since 2002 (Garrett 2002, Garrett and Verbik 2004, Verbik and Merkley 2006, 
Becker 2009, Lawton and Katsomitros 2012); see also Naidoo (2009). C-BERT maintains an online database of IBCs which updated every few months ${ }^{1}$. Table 3 uses data from the CBERT list for the 201 IBCs judged to be active and meeting its criteria in March 2014. It excludes IBCs which are known to have closed and those still under development. Table 3 shows that IBCs are predominately set up by universities in the developed 'North'; The USA, UK, Australia and France are the market leaders amongst the home countries, accounting for $138(69 \%)$ of the total. Interestingly, however, two developing countries from the 'South' (India and Malaysia) are in the top nine countries ranked by the number of IBCs set up by their universities. Nevertheless, as Figure 3 shows, when shown by the home region of origin, North America and Europe dominate the global landscape.

Representing the same data by host country, Table 3 reveals that the UAE, China (excluding Hong Kong SAR) and Singapore emerge as the main locations for IBCs; taking the UAE and Qatar together, the Middle-East accounts for 44 (22\%) of the total. IBCs are, however, less concentrated by host than home country. The 201 IBCs are spread across a total of 66 countries, with 37 countries hosting just one IBC each. In contrast, the 201 IBCs are from only 24 different home countries.

Table 3: International branch campuses by home and host country, March 2014

\begin{tabular}{|l|c|l|c|}
\hline Home Country & No. of IBCs & Host Country & No. of IBCs \\
\hline USA & 85 & UAE & 34 \\
\hline UK & 25 & China & 24 \\
\hline Australia & 16 & Singapore & 15 \\
\hline France & 12 & Qatar & 10 \\
\hline India & 9 & Canada & 7 \\
\hline Russia & 8 & France & 6 \\
\hline Germany & 6 & Malaysia & 6 \\
\hline Malaysia & 6 & UK & 5 \\
\hline Netherlands & 6 & Greece & 4 \\
\hline Other & 28 & Other & 90 \\
\hline Total & $\mathbf{2 0 1}$ & Total & $\mathbf{2 0 1}$ \\
\hline
\end{tabular}

Source: C-BERT

Table 4 shows the 13 UK universities that reported enrolments to HESA for students studying wholly at an overseas campus in 2012/13. The first three have well-known IBCs in China and Malaysia (Nottingham) and Dubai (Heriot-Watt and Middlesex). The University of Liverpool does not report enrolments at its joint venture, Xi'an Jiaotong Liverpool University, to HESA as being students at an IBC, highlighting the definitional difficulties discussed further below. The remaining universities have very limited enrolments, either because they are essentially operating their IBCs as executive education training centres (eg, London Business School, University of Exeter) or because they are on the very early stages of development (eg, University of Newcastle-upon-Tyne, University of Wales Trinity Saint David, University of Southampton).

\footnotetext{
${ }^{1}$ http://www.globalhighered.org/branchcampuses.php
} 
Table 4: Enrolments at UK international branch campuses by institution, 2012/13

\begin{tabular}{|l|c|}
\hline Higher education institution & $\begin{array}{c}\text { HE aggregate offshore students at } \\
\text { overseas campus of reporting HEI }\end{array}$ \\
\hline University of Nottingham & 9,220 \\
\hline Heriot-Watt University & 3,735 \\
\hline Middlesex University & 3,050 \\
\hline University College Birmingham & 320 \\
\hline University of Kent & 280 \\
\hline London Business School & 275 \\
\hline University of Newcastle-upon-Tyne & 250 \\
\hline University College London & 220 \\
\hline University of Exeter & 70 \\
\hline University of Wales Trinity Saint David & 45 \\
\hline University of Wolverhampton & 30 \\
\hline University of Southampton & 20 \\
\hline University of Chichester & 10 \\
\hline Total & $\mathbf{1 7 , 5 2 5}$ \\
\hline
\end{tabular}

Source: HEIDI

\section{What do we know about managing an international branch campus?}

\subsection{Why is the literature on managing international branch campuses so limited?}

The literature on managing IBCs is limited and tends to be restricted to the grey literature (eg, McBurnie and Pollock 2000, Lane et al 2004, Gow, 2007, Shattock 2007, Fielden 2008, 2011, Middlehurst et al 2009, Lane 2011b, Grant 2013, Emery and Worton 2014). There are probably at least three reasons for this. First, the phenomenon of the IBC is relatively new. Second, the operation of IBCs is shrouded in commercial secrecy. Third, the campuses are remote and most of the faculty are locally hired, so that there is not the usual interchange of information through informal networks.

\subsection{Managing staff in international branch campuses}

In terms of the challenges of managing IBCs, the richest vein of enquiry has been by faculty from the home university using their own experience to explore the difficulties of working in a foreign culture (eg, McCully, McDaniel and Roth 2009, Smith 2009, Dobos 2011, Chapman et al 2014). These studies explore the tensions of experienced by seconded expatriate staff of trying to 'serve two masters', with the staff torn between the natural allegiance to their students and local colleagues and their loyalty to their home university and its culture and procedures.

A closely related challenge for expatriate staff is teaching students who have very different learning styles and cultural frames of reference (Bodycott and Walker 2000, Dunn and Wallace 2004, 2006, Ziguras 2008, Hoare 2013). Staff may also be exposed to alien set of moral values, where, for example, giving lavish gifts may be regarded as an acceptable way to win favourable treatment from examiners.

Smith (2014) looked at the challenges for managers of dealing with 'flying faculty', who are sent from the home campus for short periods to support teaching and quality assurance at the 
IBC. The motivations of the flying faculty are varied (eg, they may accept a one-off teaching assignment as a form of 'academic tourism' with no long term commitment to the venture) and the manager of the IBC may have no formal line management over the staff while they are on his/her campus (Seah and Edwards 2006).

Hughes (2011) provides a rare account of the difficulties of managing academic staff at an IBC from her own experience at the University of Nottingham. She notes that 'there is often a tension between an individual's career expectations and what his or her institution provides... [and] the branch campus environment and the nature of university teaching can exacerbate the situation' (p.26). She discusses a number of such tensions between expatriate managers and locally-employed academic staff, including inferior terms and conditions for staff employed by the IBC relative to the home campus, lack of support for professional development and limited scope for career advancement.

An exploratory study by Eldridge and Cranston (2009) used Hofstede's cultural value dimensions to explore the link between the management style employed by leaders of IBCs and national culture. They found that the greater the cultural distance between expatriate managers and locally hired staff, the greater the potential for miscommunication and distrust.

Shams and Huisman (2014) argue that for strategic reasons, IBCs tend to retain close links with their home universities in terms of identity, curriculum and processes, but seek to localise the staff base to reduce operating costs and establish legitimacy with local stakeholders. This creates a potential tension between both the locally hired academic staff, who are usually on inferior terms and conditions, and the seconded expatriate staff ad senior managers. They conclude that 'staffing will continue to be the biggest strategic challenge faced by IBCs' (Shams and Huisman 2014, p.2).

\subsection{Managing students in an international branch campus}

A fruitful area of enquiry has been the study of how and why students choose to study at IBCs, rather than opting for a local higher education provider or looking offshore for their higher education (eg, Nguyen and LeBlanc 2001, Wilkins and Huisman 2011, 2013, Wilkins et al 2012). Some studies have found that students at IBCs experience conflicts of identity, since they are neither international students studying at an offshore institution nor domestic students studying at a local university (eg, Chapman and Pyvis 2006).

Most obviously, students in IBCs are likely to have difficulty adapting their learning styles to the teaching methods promulgated by the home university (Kelly and Tak 1998, Wang 2008, Humfrey 2009, Pimpa 2009, Heffernan et al 2010, Prowse and Goddard 2010, Marginson 2011, O'Mahoney 2014). Unlike an international student, who leaves his/her own country to be immersed in the culture of the host country while studying overseas, the student at an IBC remains in the home country. This may make it harder to adapt to the teaching environment on campus, which is effectively a small bubble of foreign culture which the students only experience for part of each day (Pyvis and Chapman 2005).

Walton and Guarisco (2007) undertook a qualitative research study which highlights this tension. One of their interviewees commented on the difficulties of using an 'AngloAmerican' pedagogy to teach Russian students in a transnational partnership, observing that 'traditionally the Russian higher education system has been based on the German one, where the teacher or lecturer is a guru who tells stupid kids what they should do... They are 
supposed to take notes, learn by heart, think for a while, and then present what they have learned at examination'(p.360).

Miliszewska and Sztendur (2012) report that students at IBCs sometimes experience low satisfaction with the physical and staff resources. This may result from the difference between the 'brand promise' of the home university, which as a major university is known for the quality of its campus, libraries and information technology, and the reality of a small branch campus where resources are very limited.

\subsection{Managing academic quality in an international branch campus}

Together with managing staff in IBCs, the management of academic quality at IBCs is the other most widely researched area (eg, Hodson and Thomas 2001, Coleman 2003, Castle and Kelly 2004, Craft 2004, Cheung 2006, Stella 2006, Blackmur 2007, Smith 2010, Edwards et al 2010, Lim 2010). This is because a key challenge for universities, regulators and policymakers with TNE is quality assurance (Martin 2007). The reputations of individual universities and national higher education systems are, in large part, based on the perceived quality of their academic awards.

Providing education across borders exposes universities to varying degrees of reputational risk. Distance-learning courses may be compromised by online fraud (eg, learners using friends to complete assessments). Franchise and validation arrangements may be undermined by the 'principal-agent' problem, with the partner colleges (agents) having different objectives (eg, profit maximisation rather than academic quality) from the awarding universities (principals); see Healey (2014a). This is a specific example of the more general "problem of inducing an "agent" to behave as if he were maximizing the "principal's" welfare' (Jensen and Meckling 1976, p.309).

While IBCs are generally regarded as towards the low risk end of the spectrum, maintaining quality control in IBCs may be more difficult because managers and staff operate in an alien culture far from the home campus. Because so many of the staff are locally hired, they may share different value sets from their managers and find it hard to apply academic regulations and procedures set far away in the home university. There are well-known examples of the reputational damage to universities of failed TNE ventures. Most famously, in 2011 the decision was taken to close the University of Wales, after official investigations revealed that it was unable to assure the quality of education in its 130 partner colleges (Henry 2011).

One of the special complexities of managing academic quality in an IBC is that, in an increasing number of host markets, the managers have to satisfy the regulatory requirements of both the home governmental agency (for UK-origin IBCs, the Quality Assurance Agency) and the host governmental agency (McBurnie and Ziguras 2001). In Malaysia, for example, IBCs are subject to regulation by the Malaysian Qualifications Agency, which specifies the curriculum requirements, and the Ministry of Education, which controls enrolment numbers and tuition fees. A key challenge for quality assurance in transnational ventures is the extent to which the metrics should be adapted to local conditions (Pyvis 2011). 


\subsection{Managing the curriculum at an international branch campus}

Managing the curriculum is closely related to the issue of managing quality assurance. Prima facie, it would appear to follow that the more precisely the curriculum at the IBC mirrors its counterpart at the home campus, the lower the risk that quality is compromised. In principle, the degrees at the IBC could follow exactly the same curriculum in terms of content and learning outcomes, with the students being assessed using common assignments and unseen examinations. The University of London, for example, uses standardised examinations to assess students in its International Programmes to guarantee uniformity of learning outcomes.

At the same time, there are legitimate pressures to adapt the content, pedagogy and assessment (Willis 2004, 2005). Most obviously, some of the content may be inapplicable to the local context. For example, most business studies degrees include one or more modules on business law, which is jurisdictionally specific. To maintain the relevance of the degree, it would make sense to substitute a module on English business law for one based on the legislation of the host country. Some content may be judged culturally inappropriate or insensitive (eg, a module on feminist literature in a staunchly Islamic country).

It is also conceivable that, for social and cultural reasons, trying to force the pedagogical approach of the home campus onto locally-hired academic staff and students may be suboptimal. Staff and students in East Asia, for example, may be uncomfortable about using a Western case study approach to learning, which blurs the conventional distinction between teacher and student. Some critics have warned of the dangers of forcing IBCs to conform to the curriculum and assessment requirements of the home campus, warning that it leads to and inappropriate and damaging degree of homogenisation (eg, Liston 1998) and a "one world culture that has the potential to undermine local differences" (Egege and Kutieleh 2008, p.68).

Pyvis (2011) argues transnational education risks promoting 'educational imperialism' (p.733); see also Rhee and Sagaria (2004). In a powerful attack on the role of western education, Tikly (2004) argued that indoctrinating students in developing countries 'into a western way of thinking based on western forms of knowledge, [is] part of a process that scholars... have described as a "colonisation of the mind" (p.188). For the managers of IBCs, there is a tension between respecting the quality assurance regime of the home campus (and home country regulators) with the need to adapt content, delivery and assessment to local needs and constraints (Waterval et al 2014).

\subsection{Managing an international branch campus as a mode of market entry}

A number of the studies have looked at the challenge of managing an IBC by drawing on international business literature (eg, Gore 2012, Lane and Kinser 2012, Wilkins and Huisman 2012). The underlying principle has been that researchers in higher education can learn from the extensive and well-established literature on the internationalisation of corporations (eg, Johanson and Vahlne 1977, 1990, Agarwal 1980, Dunning 1980, 1981, Dunning and Lundan 2008a, 2008b).

The so-called 'stages model' views companies as approaching internationalisation in incremental stages, first exporting, then licensing production to markets which are 
increasingly geographically or culturally distant from their home market and finally entering into production themselves through foreign direct investment. 'There is a loop process between the market and the firm whereby market knowledge leads to commitment decisions in the firm, the ensuing marketing activities in their turn leading to increased market commitment and knowledge, and so on' (Solberg and Durrieu 2006, p.60).

Dunning (1980) offered a more 'eclectic paradigm', arguing that the choice of foreign market entry mode was not necessarily sequential, but primarily depended on three factors:

- Ownership-specific (O) advantages (eg, trademarks, production technologies, managerial models) which give the company a competitive advantage over less efficient rivals in foreign markets.

- Location-specific (L) advantages (lower cost labour, higher demand) which make it attractive to locate production in a foreign market.

- Internalisation (I) advantages, which make it more profitable to set up a foreign production site through foreign direct investment (FDI), rather than licensing (or franchising) production to a third party. This is based on transaction cost theory, which suggests that companies will internalise activities if the internal costs are lower than the transactions costs in the external market.

The OLI Model suggests that companies will choose FDI over licensing production if there are significant internalisation advantages. UK universities clearly possess ownership-specific (O) advantages, in terms of the global brand value of their degrees, and the high demand from foreign students who are not internationally mobile creates location-specific (L) advantages in terms of being able to satisfy this demand by in-country provision. The primary advantage of internalisation (I) is that, by setting up an IBC rather than relying on an agent to franchise its programmes, the university can retain control over the quality of both enrolments and its graduates, preserving its institutional brand value. This may explain why high-status universities like Monash and Nottingham have eschewed franchising in favour of off-shore campuses to internalise their ownership advantages.

This broad approach has been has been used, either explicitly or implicitly, to study the growth of IBCs (Larsen et al 2004, Verbik and Merkley 2006), universities' motives for establishing IBCs and the conceptual frameworks for strategies for managing them (Shams and Huisman 2012, Lane 2011b). An obvious limitation of this approach is that universities differ from corporations in a number of ways, notably having a wider range of stakeholders (which include government, society and alumni), unique governance structures, noncommercial missions and restrictive national regulatory environments (Baldridge 1971, Slaughter and Leslie 1997, Meyer et al 2007, Blackman and Kennedy 2009, Stefenhagena 2012).

\subsection{Managing an international branch campus as a foreign joint venture}

There is a closely related literature on multinational corporations which has investigated aspects of the role and behaviour of managers in foreign subsidiaries by drawing on theory from international human resource management (HRM). Banai and Reisel (1993), for example, examined the organisational commitment (ie, loyalty to the parent corporation) of expatriate managers of foreign subsidiaries. Paik and Ando (2011) and Harzing (2001) looked at the roles, attributes and skills of parent country national managers vis-à-vis host country national managers in foreign subsidiaries. 
These studies suggest that the expatriate managers of IBCs may face a number of tensions. Some parallel those faced by all staff working in an IBC, with split loyalty to their local colleagues and students on the one hand, and to the home university on the other (Hedlund 1984). The international HRM literature suggests that all managers have a tendency to begin to identify more closely with their local colleagues than 'head office' over time, a tendency which multinational corporations seek to manage by rotating senior managers between posts and even countries. This tendency is also greater when the managers are locally hired; indeed, they may have no understanding of the culture of head office and identify only with the local subsidiary.

This literature suggests that managers of IBCs may find it harder to remain focused on their role as an agent of the home university the longer the period of secondment. Perhaps a more important consideration is that, unlike a more conventional joint venture, the objective functions of the university and the local partners in an IBC may be quite dissimilar. Many IBCs involve local partners drawn from the property development or financial sectors, rather than local educational institutions. These local partners may operate in a more overtly commercial way and have a much more focused profit-maximisation goal than the university partner. For the manager of the IBC, this may make liaising between the home university and the local partners increasingly challenging, especially if his/her sympathies begin to shift in favour of the latter over time.

\subsection{Managing the host government}

A number of studies have explored the phenomenon of the education hub, in which the host government deliberately attracts foreign universities to establish IBCs (eg, Knight 2007, 2011, 2012, Mok 2008, Lane 2011b, McBurnie and Ziguras 2009, Wilkins 2010, Sidhu et al 2011). As Becker (2009) notes, 'international branch campus plans do not always originate from the providing institutions anymore. Increasingly, campus proposals have been initiated by government leaders or other organisations in host countries' (p.2).

The government's goal may be to increase the absorptive capacity of the domestic higher education and/or to improve the quality of the domestic higher education sector by increasing competition for students and providing a role model ('demonstration effect'). Alternatively, the goal may be to use the foreign IBCs to attract international students, who would not be willing to study at local institutions or, instead, to service the educational needs of local residents (eg, the children of foreign expatriate workers) who are barred from accessing subsidised places in the public universities.

While the Singapore Government was an early mover in setting out its vision to become an education hub for south-east Asia through its 'Global Schoolhouse' project, it is some of the Middle East governments that have executed the education hub concept most aggressively. Dubai, for example, built the Dubai Knowledge Village as a 'university in waiting', with student dormitories, libraries and social and catering facilities, as well as classrooms and offices. The Knowledge Village was established as a tax-free zone and foreign universities could rent offices and classrooms and set up IBCs, which were licenced not by the Federal Ministry of Education but by a new Knowledge and Human Development Agency (KHDA).

Managing an IBC in an educational hub brings with it additional challenges, because of the need to liaise closely with the relevant government senior officials (Bolton and Nie 2010, Lane 2011a, Farrugia and Lane 2013). Often, these officials operate in a different cultural 
context and have different ways of doing business, which can challenge the expatriate managers of IBCs. There is also the risk that, without close liaison with government officials, the managers of the IBCs may be caught out by unexpected changes in host government policy or are unable to fathom deeply arcane local legislation and regulations. In both China and Malaysia, the IBCs of UK universities have set up informal networking forums to better manage their interactions with the host governments and regulatory authorities.

\section{Conclusions}

The fragmented nature of the research in this new and emerging area of study means that there is no orthodox theoretical framework within which IBCs are problematized. Indeed, Tight (2004) has argued that atheoretical approaches dominate higher education research generally, dubbing it an 'a-theoretical community of practice'. One explanation for this is the dominance of the 'grey literature' in this field, with much of the research being published by organisations like the Observatory for Borderless Higher Education (OBHE), the British Council, the United Nations Educational, Scientific and Cultural Organization (UNESCO), etc, which are aimed at a practitioner audience rather than academic scholars (Kehm and Teichler 2007).

This review of the academic literature on the management of IBCs reveals that managers are faced with a range of challenges, which primarily stem from dealing with key stakeholder groups: students, staff, home and host country quality regulators, the home university and the host government, as well as the IBC's local joint venture partners. The ease with which the managers can balance competing interests depends, inter alia, on the motivations of the home university for establishing the IBC, the regulatory environment in the host country and the cultural and linguistic distance between the home and host countries.

There are a number of ways in which this literature might be developed and extended to improve our understanding of the challenges of managing an IBC. First, through an exploratory investigation with the managers of IBCs, the key dimensions of the IBC which are the focus of the standardisation-localisation trade-off could be more rigorously established. This list may include additional issues like the degree of localisation of the quality assurance or ownership of the IBCs. Second, it would be instructive to develop a clearer understanding of the key factors which influence the choice of trade-off for a given dimension (eg, what are the main factors that lead an IBC to localise its curriculum?). Finally, it would be interesting to develop a clearer understanding of the dynamic forces which lead to the optimal trade-offs changing over time. As Healey (2014b) has argued, the 'mother-daughter' relationship is widely used in discourse by IBC managers, suggesting that there is an urge for greater autonomy that naturally builds up as the IBC matures.

\section{References}

Agarwal, J., 1980. Determinants of foreign direct investment: a survey. Review of World Economics, 116(4), pp739-773.

Altbach, P., 2004. Globalization and the university: myths and realities in an unequal world. Tertiary Education and Management, 10(1), pp3-25. 
Altbach, P. and Knight, J., 2007. The internationalization of higher education: motives and realities, Journal of Studies in International Education 11(3-4), pp290-305.

Altbach, P., Reisberg, L. and Rumbley, L., 2009. Trends in global higher education: tracking an academic revolution. A Report Prepared for the UNESCO 2009 World Conference on Higher Education. Available from: http://unesdoc.unesco.org/images/0018/001831/183168e.pdf [Accessed 20 December 2012].

Baldridge, J., 1971. Power and conflict in the university: research in the sociology of complex organizations. New York: Wiley.

Banai, M. and Reisel, W. 1993. Expatriate managers' loyalty to the MNC: myth or reality? An exploratory study. Journal of International Business Studies, 24(2), pp233-248.

Banks, M., and McBurnie, G., 1999. Embarking on an educational journey: the establishment of the first foreign full university campus in Malaysia under the 1996 Education Acts: A Malaysian-Australian case study. Higher Education in Europe, 24, pp265-272.

Becker, R. 2009. International branch campuses: markets and strategies. The Observatory on Borderless Higher Education. Available from: http://www.obhe.ac.uk/documents/view_details?id=770 [Accessed 6 June 2012].

Bennell, P. and Pearce, T., 2003. The internationalisation of higher education: exporting education to developing and transitional economies', International Journal of Educational Development, 23(2) pp215-232.

Bhanji, Z., 2008. Transnational corporations in education: filling the governance gap through new social norms and market multilateralism? Globalisation, Societies and Education, 6(1), pp55-73.

Blackman, D. and Kennedy, M., 2009. Knowledge management and effective university governance. Journal of Knowledge Management,13(6), pp547-563.

Blackmur, D., 2007. A critical analysis of the UNESCO/OECD guidelines for quality provision of cross-border higher education. Quality in Higher Education, 13(2), pp117-130.

Bodycott, P. and A. Walker., 2000. Teaching abroad: lessons learned about intercultural understanding for teachers in higher education. Teaching in Higher Education, 5(1) pp79-94.

Bolton, D. and Nie, R., 2010. Creating value in transnational higher education: the role of stakeholder management. Academy of Management Learning and Education, 9, pp701-714.

British Council, 2012. The shape of things to come: higher education global trends and emerging opportunities to 2020. Available from: http://ihe.britishcouncil.org/news/shapethings-come-higher-education-global-trends-and-emerging-opportunities-2020 [Accessed 20 June 2012].

British Council, 2013. The shape of things to come. The evolution of transnational education: data, definitions, opportunities and impact analysis. Available from: 
http://www.britishcouncil.org/sites/britishcouncil.uk2/files/the_shape_of_things_to_come_2. pdf [Accessed 14 September 2013].

Burgess, P. and Berquist, B., 2012. Cross-border delivery: programs, programs, and providers. In Deardorff, D., de Wit, H., Heyl, J. and Adams, T. (eds.) The SAGE handbook of international higher education. London: SAGE, pp325-342.

Castle, R. and Kelly, D., 2004. International education: quality assurance and standards in offshore teaching: exemplars and problems. Quality in Higher Education, 10(1), pp51-57.

C-BERT, n.d. Branch campus listing (Updated November 1, 2014). Available from: http://www.globalhighered.org/branchcampuses.php [Accessed 6 December 2014].

Chapman, A. and Pyvis, D., 2006. Dilemmas in the formation of student identity in offshore higher education: a case study in Hong Kong. Educational Review, 58, pp291-302.

Chapman, D., Austin, A., Farah, S, Wilson, E. and Ridge, N., 2014. Academic staff in the UAE: unsettled journey. Higher Education Policy, 27, pp131-151.

Cheung, P., 2006. Filleting the transnational education steak. Quality in Higher Education, 12(3), pp283-285.

Coleman, D., 2003. Quality assurance in transnational education. Journal of Studies in International Education, 7, pp354-378.

Craft, A., 2004. The assessment of quality risks in collaborative provision. Quality in Higher Education, 10(1), pp25-29.

De Wit, H., 2002. Internationalization of higher education in the United States of America and Europe: a historical, comparative, and conceptual analysis. London: Greenwood Press.

Dobos, K., 2011. "Serving two masters"- Academics' perspectives on working at an offshore campus in Malaysia. Educational Review, 63, pp19-35.

Donn, G. and Al Manthri, Y., 2010. Globalisation and higher education in the Arab Gulf States. Oxford: Symposium Books.

Doorbar, A. and Bateman, C., 2008. The growth of transnational higher education: the UK perspective. In Dunn, L. and Wallace, M. (eds). Teaching in transnational higher education, New York: Routledge.

Drew S., Tang N., Poole G. and Willis B., 2006. Trans-national education - UK higher education institutions' response to increasing global demand: summary report. Manchester: British Council.

Dunn, L. and Wallace, M., 2004. Australian academics teaching in Singapore: striving for cultural empathy. Innovations in Education and Teaching International, 41, pp291-304. 
Dunn, L. and Wallace, M., 2006. Australian academics and transnational teaching: an exploratory study of their preparedness and experiences. Higher Education Research and Development, 25, pp357-369.

Dunning, J., 1980. Towards an eclectic theory of international production: some empirical tests. Journal of International Business Studies, 11(1), pp9-31.

Dunning, J., 1981. International production and the multinational enterprise. London: Allen and Unwin.

Dunning, J. and Lundan, S., 2008a. Institutions and the OLI paradigm of the multinational enterprise. Asia Pacific Journal of Management, 25, pp573-593.

Dunning, J. and Lundan, S., 2008b. Multinational enterprises and the global economy (2nd ed.). Cheltenham: Edward Elgar.

Edwards, J., Crosling, G. and Edwards, R., 2010. Outsourcing university degrees: implications for quality control. Journal of Higher Education Policy and Management, 32(3), pp303-315.

Egege, S. and Kutieleh, S., 2009. Dimming down difference. In Dunn, L. and Wallace, M. (eds.) Teaching in transnational higher education: enhancing learning for offshore international students. London: Routledge, pp67-76.

Eldridge, K. and Cranston, N., 2009. Managing transnational education: does national culture really matter? Journal of Higher Education Policy and Management, 31(1), pp67-79.

Emery, V., and Worton, M., 2014. Challenges for the leadership of transnational education in higher education: balancing risk and innovation. London: Leadership Foundation.

Ennew, C. and Yang, F., 2009. Foreign universities in China: A case study. European Journal of Education, 44(1), pp21-36.

Farrugia, C. and Lane, J., 2013. Legitimacy in cross-border higher education: identifying stakeholders of international branch campuses. Journal of Studies in International Education, 17(4), pp.414-432.

Feng, Y., 2013. University of Nottingham Ningbo China and Xi'an Jiaotong-Liverpool University: globalization of higher education in China. Higher Education, 65(4), pp471-485.

Fielden, J., 2008. The practice of internationalisation: managing international activities in UK universities. Research Series, 1. London: UK Higher Education International Unit.

Fielden, J., 2011. Leadership and management of international partnerships. London: Leadership Foundation and LH Martin Institute.

Garrett, R. (2002) International branch campuses: scale and significance, Redhill: Observatory on Borderless Higher Education. Available from: http://www.obhe.ac.uk/documents/view_details?id=574 [Accessed 20 September 2012]. 
Garrett, R. and Verbik, L. 2003. Transnational higher education, part 1: the major markets Hong Kong and Singapore. Redhill: Observatory on Borderless Higher Education. Available from: http://www.obhe.ac.uk/documents/view_details?id=703 [Accessed 6 June 2012].

Garrett, G. and Verbik, L, 2004. Transnational delivery by UK higher education, Part 1: data and missing data, Redhill: Observatory on Borderless Higher Education. Available from: http://www.obhe.ac.uk/documents/view_details?id=63 [Accessed 6 June 2012].

Garrett, R., 2004. Transnational delivery by UK higher education, part 2: innovation and competitive advantage. Redhill: Observatory on Borderless Higher Education. Available from: www.obhe.ac.uk/documents/download?id=62 [Accessed 6 June 2012].

Girdzijauskaite, E. and Radzeviciene, A., 2014. International branch campus: framework and strategy. Procedia Social and Behavioral Sciences, 110(24), pp301-308.

Gore, T., 2012. Higher education across borders: models of engagement and lessons from corporate strategy, Redhill: Observatory on Borderless Higher Education. Available from: www.obhe.ac.uk/documents/download?id=895 [Accessed 20 August 2012].

Gow, I., 2007. Removing the rose-tinted spectacles. In Fazackerley, A. and Worthington, P. (eds.) British universities in China: the reality beyond the rhetoric. AGORA Discussion Paper. London: AGORA, pp7-9.

Grant, C., 2013. Losing our chains? Contexts and ethics of university internationalisation. London: Leadership Foundation for Higher Education.

Gu, J., 2009. Transnational education: current developments and policy implications. Frontiers of Education in China, 4, pp624-649.

Harzing, W., 2001. Of bears, bumble-bees, and spiders: the role of expatriates in controlling foreign subsidiaries. Journal of World Business, 36(4), pp366-379.

Hatakenaka S., 2004. Internationalism in higher education: a review. Oxford: Higher Education Policy Institute.

Healey, N., 2008. Is higher education in really internationalising? Higher Education, 55(3), pp333-355.

Healey, N., 2013. Is UK transnational education 'one of Britain's great growth industries of the future'?, Higher Education Review, 45(3), pp6-35.

Healey, N., 2014a. Towards a risk-based typology for transnational education. Higher Education, DOI: 10.1007/s10734-014-9757-6.

Healey, N., 2014b. When is an international branch campus? International Higher Education, $78, \mathrm{pp} 22-23$.

Healey, N. and Bordogna, C., 2014. From transnational to multinational education: emerging trends in international higher education. Internationalisation of Higher Education, 3, pp34-56. 
Hedlund, G., 1984. Organization in-between: the evolution of the mother-daughter structure of managing foreign subsidiaries in Swedish MNCs. Journal of International Business Studies, 15(2), pp109-123.

Heffernanan, T., Morrison, M., Basu, P. and Sweeney, A., 2010. Cultural differences, learning styles and transnational education. Journal of Higher Education Policy and Management, 32(1), pp27-39.

HEIDI, n.d. Higher Education Information Database for Institutions. Available from: https://heidi.hesa.ac.uk/home.aspx [Accessed 28 March 2014].

Helms, R., 2008. Transnational education in China: key challenges, critical issues, and strategies for success. London, UK: The Observatory on Borderless Higher Education. Available from: http://www.obhe.ac.uk/documents/view_details?id=11 [Accessed 13 June 2012].

Henry, J. (2011). University of Wales abolished after visa scandal. The Telegraph. Available from: http://www.telegraph.co.uk/education/educationnews/8843200/University-of-Walesabolished-after-visa-scandal.html [Accessed 22 October 2011].

Hoare, L., 2013. Swimming in the deep end: transnational teaching as culture learning? Higher Education Research and Development, 32(4), pp561-574.

Hodson, P. and Thomas, H., 2001. Higher Education as an international commodity: ensuring quality in partnerships, Assessment and Evaluation in Higher Education, 26(2), pp101-112.

Huang, F., 2003. Transnational higher education: a perspective from China. Higher Education Research and Development, 22(2), pp193-203.

Huang, F., 2007. Internationalization of higher education in the developing and emerging countries: a focus on transnational higher education in Asia. Journal of Studies in International Education, 11(3/4), pp.421-432.

Hughes, R., 2011. Strategies for managing and leading an academic staff in multiple countries. New Directuions for Higher Education, 155, 19-28.

Humfrey, C., 2009. Transnational education and the student experience: a PMI student experience project report, UK Council for International Student Affairs. Available from: http://www.ukcosa.org.uk/files/pdf/pmi/tne_report.pdf [Accessed 25 November 2012].

Ilieva, J., 2011. Global Gauge: East Asia. Hong Kong: British Council.

Jensen, M. and Meckling, W., 1976. Theory of the firm: managerial behavior, agency costs and ownership structure', Journal of Financial Economics, 3, pp305-360.

Johanson, J. and Vahlne, J.-E., 1977. The internationalization process of the firm - a model of knowledge development and increasing foreign market commitment. Journal of International Business Studies, 8(1), pp23-32. 
Johanson, J. and Vahlne, J.-E., 1990. The mechanism of internationalization. International Marketing Review, 7(4), pp11-24.

Kelly, M. and Tak, S., 1998. Borderless education and teaching and learning cultures: the case of Hong Kong. Australian Universities' Review, 41(1), pp26-33.

Kehm, B. and Teichler, U., 2007. Research on internationalisation in higher education. Journal of Studies in International Education, 11, pp260-173.

Knight, J., 2005. Borderless, offshore, transnational and crossborder education: definition and data dilemmas, Redhill: Observatory on Borderless Education. Available from:

http://www.obhe.ac.uk/documents/view_details?id=35\&gt [Accessed 6 February 2012].

Knight, J., 2006. Cross-border education: Conceptual confusion and data deficits.

Perspectives in Education, 24, pp15-27.

Knight, J., 2007. Cross-border tertiary education: an introduction. In Vincent-Lancrin, S., (ed.) Cross-border tertiary education: a way towards capacity development. Paris:

Organisation for Economic Cooperation and Development and The World Bank, pp21-46.

Knight, J., 2011. Education hubs: a fad, a brand, an innovation? Journal of Studies in International Education, 15(3), pp221-240.

Knight, J., 2012. Internationalization: three generations of crossborder higher education, Occasional Paper 38. New Delhi: India International Centre. Available from:

http://www.iicdelhi.nic.in/publications/uploads_diary_files/53511July92012_IIC\%20Occasio nal\%20Publication\%2038.pdf [Accessed: 11 March 2014].

Lane, J., Brown, M. and Pearcey, M., 2004. Transnational campuses: obstacles and opportunities for institutional research in the global education market. New Directions for Institutional Research, 124, pp49-62.

Lane, J., 2011a. Importing private higher education: international branch campuses. Journal of Comparative Policy Analysis, 13(4), pp367-381.

Lane, J., 2011b. Global expansion of international branch campuses: managerial and leadership challenges. New Directions for Higher Education, 155, pp5-17.

Lane, J. and Kinser, K., 2012. International branch campuses: one definition to rule them all? Available from: http://chronicle.com/blogs/worldwise/international-branch-campuses-onedefinition-to-rule-them-all/29051 [Accessed 6 February 2013].

Lane, J. and Kinser, K., 2013. Five models of international branch campus facility ownership, International Higher Education, 70, 9-10.

Larsen, K., Momii, K. and Vincent-Lancrin, S. (2004) Cross-border higher education: an analysis of current trends, policy strategies and future scenarios, Redhill: The Observatory on Borderless Higher Education. Available from:

http://www.obhe.ac.uk/documents/view_details?id=49 [Accessed 19 October 2012]. 
Lawton, W. and Katsomitros, A. (2012) International branch campuses: data and developments. Redhill: The Observatory on Borderless Higher Education. www.obhe.ac.uk/documents/download?id=894 [Accessed 22 August 2012].

Lien, D. (2008). Economic analysis of transnational education. Education Economics, 16, 149-167.

Lien D, Wang Y., 2012. The effects of a branch campus. Education Economics, Vol.20 (4), p.386-402.

Lim, F., 2010. Do too many rights make a wrong? A qualitative study of the experiences of a sample of Malaysian and Singapore private higher education providers in transnational quality assurance. Quality in Higher Education, 16(3), pp211-222.

Liston, C. (1998): Effects of transnational tertiary education on students: proposing an assessment model. Available at:

http://www.aair.org.au/app/webroot/media/pdf/AAIR\%20Fora/Forum1998/Liston.pdf [Accessed 02 May 2014].

Marginson, S., 2011. Higher education in East Asia and Singapore: rise of the Confucian Model. Higher Education, 61, pp587-611.

Marginson, S. and Van der Wende, M., 2007. Globalisation and higher education. OECD Education Working Papers No. 8. Paris: OECD. doi:10.1787/173831738240.

Martin, M., ed. (2007) Cross-border higher education: regulation, quality assurance and impact, Paris: UNESCO. Available from:

http://unesdoc.unesco.org/images/0015/001538/153897e.pdf [Accessed 6 June 2012].

Mazzarol, T. and Soutar, G., 2002. "Push-pull" factors influencing international student destination choice. International Journal of Educational Management, 16(2), pp.82-90.

Mazzarol, T., Soutar, G. and Seng, M., 2003. The third wave: future trends in international education. International Journal of Educational Management, 17(2/3), pp90-99.

McBurnie, G. and Pollock, A., 2000. Opportunity and risk in transnational education: issues in planning for international campus development: an Australian perspective. Higher Education in Europe, 25(3), pp333-343.

McBurnie, G., and Ziguras, C., 2001. The regulation of transnational higher education in southeast Asia: case studies of Hong Kong, Malaysia and Australia. Higher Education, 42, 85-105.

McBurnie, G., and Ziguras, C., 2007. Transnational education: issues and trends in offshore higher education. London: Routledge.

McBurnie, G. and Ziguras, C., 2009. Trends and future scenarios in programme and institution mobility across borders, in Higher Education to 2030 Volume 2: Globalization, Paris: Organisation for Economic Cooperation and Development, pp89-108. 
McCully, M., McDaniel, E. and Roth, B., 2009. Faculty challenges in educating international students and faculty on their home turf. Proceedings of the 6th International Conference on Intellectual Capital, Knowledge Management and Organisational Learning.

McNamara, J. and Knight, J., 2014. Impacts of transnational education on host countries: academic, cultural, economic and skills impacts and implications of programme and provider mobility. London: British Council and DAAD.

Meyer, J., Ramirez, F., Frank, D. and Schofer, E., 2007. Higher education as an institution. In Gumport, P. (ed.) Sociology of higher education: Contributions and their contexts. Baltimore: Johns Hopkins University Press, pp187-221.

Middlehurst, R., Woodfield, S., Forland, H., and Fielden, J. (2009). Universities and international higher education partnerships: making a difference. London: Million+. Available from: http://www.millionplus.ac.uk/research/index [Accessed 24 August 2012]

Miliszewska, I. and Sztendur, E., 2012. Australian transnational education programmes in South East Asia: Student satisfaction with the learning environment. Australian Universities' Review, 54(2), pp12-21.

Miller-Idriss, C. and Hanauer, E., 2011. Transnational higher education: offshore campuses in the Middle East. Comparative Education, 47, pp.181-207.

Mok, K., 2008. Singapore's global education hub ambitions: university governance change and transnational higher education. International Journal of Educational Management, 22, pp527-546.

Naidoo, V., 2009. Transnational higher education: a stock take of current activity Journal of Studies in International Education, 13, pp310-330.

Nguyen, N. and LeBlanc, G., 2001. Image and reputation of higher education institutions in students' retention decisions. International Journal of Educational Management, 15, 303-311.

Nguyen, P., Elliott, J., Terlouw, C. and Pilot, A., 2009. Neocolonialism in education: cooperative learning in an Asian context. Comparative Education, 45, pp109-130.

O’Mahoney, J. (2014). Enhancing student learning and teacher development in transnational education. York: Higher Education Academy.

Observatory on Borderless Higher Education, 2007. A miscalculated level of risk? UNSW Asia announces its unexpected closure. Available from:

http://www.obhe.ac.uk/documents/view_details?id=192 [Accessed 7 July 2012].

Organisation for Economic Co-operation and Development, 2013. Education at a glance 2013: OECD indicators, Paris: OECD. Available from: http://www.oecd.org/edu/eag2013\%20(eng)--FINAL\%2020\%20June\%202013.pdf [Accessed 26 August 2013] 
Paik, Y. and Ando, N., 2011 MNC's competitive strategies, experiences, and staffing policies for foreign affiliates. The International Journal of Human Resource Management, 22(15), pp3003-3019.

Pimpa, N., 2009. Learning problems in transnational business education and training: the case of the MBA in Thailand. International Journal of Training and Development, 13, pp262-279.

Prowse, J. and Goddard, J., 2010. Teaching across cultures: Canada and Qatar. Canadian Journal of Higher Education, 40(1), pp31-52.

Pyvis, D., 2011. The need for context-sensitive measures of educational quality in transnational higher education, Teaching in Higher Education, 16(6), pp733-744.

Pyvis, D. and Chapman, A., 2005. Culture shock and the international student "offshore." Journal of Research in International Education, 4(1), pp23-42.

Quality Assurance Agency, 2009. Audit of overseas provision, India: overview report. Available from: http://www.qaa.ac.uk/en/Publications/Documents/Audit-overseas-provisionIndia-Overview-July-2009.pdf [Accessed 06 June 2012].

Quality Assurance Agency, 2010. Audit of overseas provision, Malaysia: overview report. Available from: http://www.qaa.ac.uk/en/Publications/Documents/Audit-of-overseasprovision-Malaysia-overview-report.pdf [Accessed 06 June 2012].

Quality Assurance Agency, 2011. Audit of overseas provision, Singapore: overview report. Available from: http://www.qaa.ac.uk/en/Publications/Documents/Singapore-overviewreport-AOP-11.pdf [Accessed 06 June 2012].

Quality Assurance Agency, 2012. Review of UK transnational education in China 2012: overview. Available from:

http://www.qaa.ac.uk/en/Publications/Documents/TNE-China-Overview.pdf [Accessed 12 February 2013].

Quality Assurance Agency, 2014. Review of UK transnational education in United Arab Emirates:Overview. Available from:

http://www.qaa.ac.uk/en/Publications/Documents/Review-Transnational-Education-UAE14.pdf [Access 23 September 2014].

Rhee, J. and Sagaria, M., 2004. International students: constructions of imperialism in the Chronicle of Higher Education. Review of Higher Education, 28(1), pp77-96.

Rumbley, L. and Altbach, P., 2007. International branch campus issues. London: The Observatory on Borderless Higher Education.

Salt, J. and Wood, P., 2014. Staffing UK university campuses overseas: lessons from MNE practice. Journal of Studies in International Education, 18(1), pp82-97.

Seah, W. and Edwards, J., 2006. Flying in, flying out: offshore teaching in higher education. Australian Journal of Education, 50(3), pp297-311. 
Shams, F. and Huisman, J., 2012. Managing offshore branch campuses: An analytical framework for institutional strategies. Journal of Studies in International Education, 16(2), pp106-127.

Shams, F. and Huisman, J. 2014. The role of institutional dual embeddedness in the strategic local adaptation of international branch campuses: evidence from Malaysia and Singapore. Studies in Higher Education, http://dx.doi.org/10.1080/03075079.2014.966669.

Shattock, M., 2007. Overseas campuses: the management perspective. In Fazackerley, A. and Shattock, M. (eds.). Overseas campuses: the management perspective. London: Agora: The Forum for Culture and Education.

Sidhu, R., 2009. The "brand name" research university goes global. Higher Education, 57(2), pp125-140.

Sidhu, R., Ho, K., and Yeoh, B., 2011. Emerging education hubs: The case of Singapore. Higher Education, 61(1), pp23-40.

Slaughter, S. and Leslie, L., 1997. Academic capitalism: politics, policies and the entrepreneurial university. Baltimore: John Hopkins University Press.

Smith, K., 2010. Assuring quality in transnational higher education: A matter of collaboration or control? Studies in Higher Education, 35, pp793-806.

Smith, K., 2014. Exploring flying faculty teaching experiences: motivations, challenges and opportunities. IStudies in Higher Education, 39(1), pp117-134.

Smith, L., 2009. Sinking in the sand? Academic work in an offshore campus of an Australian university. Higher Education Research and Development, 28, pp467-479.

Solberg, C. and Durrieu, F., 2006. Access to networks and commitment to internationalisation as precursors to marketing strategies in international markets. Management International Review, 46 (1), pp57-83.

Stefenhagena, D., 2012. University institutional governance in a changing environment. Economics and Management, 17(4), pp1594-1600.

Stella, A., 2006. Quality assurance of cross-border higher education. Quality in Higher Education, 12(3), pp257-276.

Tight, M, 2004. Research into higher education: an a-theoretical community of practice? Higher Education Research and Development, 23(4), pp395-411.

Tikly, L., 2004. Education and the new imperialism. Comparative Education, 40, pp173-198.

Tsiligiris, V., 2013. Transnational higher education partnerships: overcoming highereducation access barriers and 'brain-drain' reversal in Greece, in Stiasny, M. and Gore, T. (eds.). Going global: identifying trends and drivers of international education. Bingley: Emerald Group, pp55-68. 
UNESCO, 1998. World statistical outlook on higher education 1980-1995. Working document World Conference on Higher Education in the Twenty-first Century: Vision and Action. Paris: UNESCO. Available from:

http://unesdoc.unesco.org/images/0011/001136/113601eo.pdf [Accessed 12 January 2013].

UNESCO Institute for Statistics (n.d.): Higher education. Available from:

http://www.uis.unesco.org/Education/Pages/tertiary-education.aspx [Accessed 14 June 2014].

Verbik, L. and Merkley, C., 2006. The international branch campus - models and trends.

Redhill: Observatory on Borderless Higher Education. Available from:

http://www.obhe.ac.uk/documents/view_details?id=34 [Accessed 20 November 2012].

Vincent-Lancrin, S., 2007. Developing capacity through cross-border tertiary education', in Vincent-Lancrin, S. (ed.), Cross-border tertiary education: a way towards capacity development, Paris: OECD and the International Bank for Reconstruction and Development, pp47-108.

Walton, J. S., \& Guarisco, G., 2007. Structural issues and knowledge management in transnational education partnerships. Journal of European Industrial Training, 31(5), pp358376.

Wang, T., 2008. Intercultural dialogue and understanding: implications for teachers. In L. Dunn and Wallace, M. (eds.) Teaching in transnational higher education: enhancing learning for offshore international students. New York: Routledge, pp57-66.

Waterval, D., Frambach, J., Driessen, E. and Scherpbier, A., 2014. Copy but not paste: a literature review of crossborder curriculum partnerships. Journal of Studies in International Education, DOI: 10.1177/1028315314533608.

Welch, A., 2011. Higher education in Southeast Asia: blurring borders, changing balance. Abingdon: Routledge.

Wilkins, S., 2010. Higher education in the United Arab Emirates: an analysis of the outcomes of significant increases in supply and competition. Journal of Higher Education Policy and Management, 32, pp.389-400.

Wilkins, S., and J. Huisman. 2011. Student recruitment at international branch campuses: can they compete in the global market? Journal of Studies in International Educatio, 15(3), pp299-316.

Wilkins, S., Balakrishnan, M. and Huisman, J., 2012. Student choice in higher education: motivations for choosing to study at an international branch campus. Journal of Studies in International Education, 16, pp413-433.

Wilkins, S. and Huisman, J. (2012) 'The international branch campus as transnational strategy in higher education', Higher Education 64(5): 627-645.

Wilkins, S., and Huisman, J., 2013. Student evaluation of university image attractiveness and its impact on student attachment to international branch campuses. Journal of Studies in International Education, 17, pp607-623. 
Willis, M. (2004). Looking East, looking West: exploring the views of Hong Kong University students about traditional Chinese cultural values in terms of the delivery of foreign programs. Journal of Marketing for Higher Education, 13, pp159-177.

Willis, M. (2005). An evaluation of levels of adaptation used in the teaching of foreign university degree programs in China. Journal of Teaching in International Business, 16(2), pp27-49.

Ziguras, C., 2008. The cultural politics of transnational education: idiological and pedagogical issues for teaching staff. In L. Dunn and Wallace, M. (Eds.), Teaching in transnational higher education: enhancing learning for offshore international students. New York: Routledge, pp44-54.

Ziguras, C. and McBurnie, G., 2011. Transnational higher education in the Asia-Pacific region: from distance education to the branch campus. Higher Education Dynamics, 36, pp105-122. 